\title{
HUBUNGAN PENGETAHUAN, SIKAP DAN KARAKTERISTIK IBU DENGAN PERILAKU HIDUP BERSIH DAN SEHAT PADA TATANAN RUMAH TANGGA DI WILAYAH KERJA UPTD PUSKESMAS SUNYARAGI KOTA CIREBON
}

\author{
Siti Matoya*Iin Kristanti**
}

\begin{abstract}
ABSTRAK
Perilaku hidup bersih dan sehat adalah semua perilaku kesehatan yang dilakukan atas kesadaran sehingga anggota keluarga atau keluarga dapat menolong dirinya sendiri di bidang kesehatan dan dapat berperan aktif dalam kegiatankegiatan kesehatan di masyarakat. Berdasarkan data perilaku hidup bersih dan sehat tatanan rumah tangga di wilayah kerja Puskesmas Sunyaragi tahun 2013 dengan jumlah 1988 rumah tangga, status rumah tangga sehat baru mencapai 60\%. Padahal Rencana Strategis (Restra) Kementerian Kesehatan tahun 2010-2014 mencantumkan target 70\% rumah tangga sudah mempraktekkan perilaku hidup bersih dan sehat. Penelitian ini bertujuan untuk mengetahui hubungan pengetahuan, sikap dan karakteristik ibu dengan perilaku hidup bersih dan sehat pada tatanan rumah tangga di wilayah kerja Puskesmas Sunyaragi Kota Cirebon Tahun 2014.

Metode yang digunakan pada penelitian ini adalah survey analitik dengan menggunakan desain penelitian cross sectional. Hal yang ingin di teliti adalah hubungan antara pengetahuan, sikap dan karakteristik ibu dengan perilaku hidup bersih dan sehat. Pengumpulan data dilakukan dengan wawancara menggunakan kuesioner. Pengolahan dan analisa data dilakukan dengan menggunakan program SPSS (Statistic Package For Social Science) versi 18. Populasi penelitian ini adalah ibu rumah tangga yang ada di wilayah kerja UPTD Puskesmas Sunyaragi kota cirebon yaitu sebanyak 2761 responden. Jumlah sampel sebanyak 97 ibu rumah tangga yang diambil secara systematic random sampling. Data dianalisis secara statistik menggunakan Uji Chi Square pada tingkat kemaknaan 5\% $(0,05)$.

Hasil uji statistik didapatkan bahwa umur $(P$-value $=0,584)$, tidak ada hubungan antara umur dengan perilaku hidup bersih dan sehat. Tingkat pendidikan $(P$-value $)=0,000)$, ada hubungan antara tingkat pendidikan dengan perilaku hidup bersih dan sehat. Status pekerjaan $(P$-value $=1,000)$, tidak ada hubungan antara status pekerjaan dengan perilaku hidup bersih dan sehat. Pengetahuan $(P$-value $=0,000)$, ada hubungan antara pengetahuan dengan perilaku hidup bersih dan sehat. Sikap $(P$-value $=0,000)$, ada hubungan antara sikap dengan perilaku hidup bersih dan sehat.
\end{abstract}

Kata Kunci : Pengetahuan, Sikap, Karakteristik Ibu ( umur, tingkat pendidikan, status pekerjaan)

\begin{abstract}
Clean and healthy living behavior is all the health behaviors conducted on the awareness that a family member or family to help themselves in the field of health and can play an active role in the activities in public health. Based on data from a clean and healthy living behavior order households in Puskesmas Sunyaragi 2013 to 1988 the number of households, household healthy status only reached 60\%. Whereas the Strategic Plan (Restra) The Ministry of Health in 2010-2014 included a target of 70\% of households own practice clean and healthy living behavior. This study aims to determine the relationship of knowledge, attitudes and behavior characteristics of mothers with healthy and clean life in order households in Puskesmas Sunyaragi Cirebon 2014.

The method used in this research is analytic survey using cross sectional design. Things that you want to study is that the relationship between knowledge, attitude and behavior characteristics of mothers with healthy and clean life. Data was collected through interviews using a questionnaire. Processing and analysis of data using SPSS (Statistic Package For Social Science) version 18. The study population was a housewife in the working area of Puskesmas Sunyaragi UPTD Cirebon city as many as 2761 respondents. The total sample of 97 housewives who were taken by systematic random sampling. Data were statistically analyzed using Chi Square test at the 5\% significance level (0.05).

Statistical test results showed that age $(\mathrm{P}$-value $=0.584)$, there was no relationship between age and behavior of clean and healthy. The level of education (P-value) $=0,000$ ), there is a correlation between level of education and behavior of clean and healthy. Employment status $(\mathrm{P}$-value $=1.000)$, there was no association between employment status with a clean and healthy living behavior. Knowledge $(\mathrm{P}$-value $=0.000)$, there is a relationship between knowledge and behavior of clean and healthy. Attitudes $(\mathrm{P}$-value $=0.000)$, there is a correlation between attitude and behavior of healthy and clean life.
\end{abstract}

Keywords: Knowledge, Attitude, Mrs. characteristics (age, education level, employment status)

*Alumni PSKM STIKes Cirebon

**Staf Pengajar PSKM STIKes Cirebon 


\section{PENDAHULUAN}

Sehat merupakan hak asasi manusia dan merupakan intervensi untuk kehidupan yang produktif. Sehat juga merupakan prasyarat agar hidup kita menjadi lebih berarti, sejahtera, dan bahagia. Untuk mewujudkan hal tersebut seseorang wajib menjaga, memelihara dan meningkatkan kesehatan secara terus-menerus. ${ }^{1}$

Harapan tersebut dapat terwujud apabila masyarakat diberdayakan sepenuhnya dengan sumber daya yang dimilikinya untuk dapat menerapkan Perilaku hidup bersih dan sehat dalam kehidupannya sehari-hari, baik di rumah, di sekolah, di tempat kerja, Institusi Kesehatan dan Tempat-tempat umum. ${ }^{1}$

Pembangunan kesehatan diselenggarakan dengan berdasarkan perikemanusiaan, pemberdayaan, dan kemandirian, adil dan merata, serta pengutamaan dan manfaat dengan perhatian khusus pada penduduk rentan, antara lain ibu, bayi, anak, manusia usia lanjut (manula), dan keluarga miskin. Pembangunan kesehatan dilaksanakan melalui peningkatan upaya kesehatan, yaitu dengan pembiayaan kesehatan, sumber daya manusia kesehatan, obat dan perbekalan kesehatan yang disertai oleh peningkatan pengawasan, pemberdayaan masyarakat, dan manajemen kesehatan. Upaya tersebut dilakukan dengan memperhatikan dinamika kependudukan, epidemiologi penyakit, perubahan ekologi dan lingkungan, kemajuan Iptek serta globalisasi dan demokratisasi. Dengan semangat kemitraan dan kerja sama lintas sektor. Penekanan diberikan pada peningkatan perilaku dan kemandirian masyarakat serta upaya promotif dan preventif. Pembangunan nasional harus berwawasan kesehatan, yaitu setiap kebijakan publik selalu memperhatikan dampaknya terhadap kesehatan. Pembangunan dan perbaikan gizi dilaksanakan secara lintas sektor yang meliputi produksi pangan, pengolahan, distribusi, hingga konsumsi pangan tingkat rumah tangga dengan kandungan gizi yang cukup, seimbang dan terjamin keamanannya dalam rangka mencapai status gizi yang baik. ${ }^{1}$

Perilaku hidup bersih dan sehat dapat diterapkan dalam kehidupan sehari-sehari dalam lingkungan sekitar, seperti lingkungan rumah tangga, sekolah, tempat kerja dan institusi kesehatan. Perilaku hidup bersih dan sehat pada tatanan rumah tangga merupakan bentuk perwujudan paradigma sehat dalam budaya hidup perorangan dan keluarga, yang bertujuan untuk meningkatkan, memelihara dan melindungi kesehatannya. ${ }^{2}$

Keluarga merupakan unit terkecil dari suatu bangsa. Di dalam keluarga terjadi interaksi dan komunikasi antara anggota keluarga yang menjadi awal penting dari suatu proses pendidikan. Ditanamkannya Perilaku hidup bersih dan sehat sejak dini dalam keluarga dapat menciptakan keluarga yang sehat. Keluarga yang sehat akan membentuk masyarakat, desa dan kelurahan, kecamatan, kabupaten, provinsi dan bangsa yang sehat. Bangsa yang sehat memiliki derajat kesehatan yang tinggi, sehingga meningkatkan produktivitas bangsa tersebut. ${ }^{2}$

Dalam rumah tangga ibu mempunyai peran yang sangat besar dalam memberi contoh, teladan, pendidikan di suatu keluarga daripada ayah. Ibu juga lebih mendominasi dalam hal pengaturan menu makanan dan menjaga kebersihan rumah, termasuk di dalam memberikan pendidikan kesehatan di keluarga, seperti menanamkan perilaku hidup bersih dan sehat. ${ }^{3}$

Pemerintah telah melakukan berbagai upaya dalam meningkatkan derajat kesehatan tersebut antara lain melalui perubahan perilaku dengan menerapkan Program Perilaku Hidup Bersih dan Sehat (PHBS) Kab/Kota sehat. Program perilaku hidup bersih dan sehat telah diluncurkan sejak tahun 1996 oleh Departemen Kesehatan yaitu oleh Pusat Penyuluhan Kesehatan Masyarakat yang saat ini disebut Pusat Promosi Kesehatan, namun sampai sekarang hasilnya belum memenuhi harapan. ${ }^{4}$

Menurut indeks pembangunan kesehatan masyarakat tahun 2010, rata-rata persentase perilaku hidup bersih dan sehat (PHBS) nasional hanya 35,68\%, artinya hanya 35,68\% dari total warga Indonesia yang telah berperilaku hidup bersih dan sehat. ${ }^{5}$

Secara keseluruhan perilaku tidak sehat tentunya berisiko mengundang datangnya berbagai penyakit. Tidak mustahil bila kasus-kasus penyakit akibat perilaku tidak sehat seperti jantung koroner, diabetes tipe II, hipertensi dan obesitas masih banyak ditemukan. Penyakit Diare, Ispa Penyakit ini lebih banyak dipengaruhi kondisi sanitasi lingkungan yang buruk seperti akses air bersih yang belum dinikmati semua lapisan dan jamban sehat yang juga belum dipunyai disetiap 
rumah tangga. Selain dipengaruhi oleh perilaku dan sanitasi lingkungan, kesehatan masyarakat juga dipengaruhi oleh tingkat ekonomi sosial dan pendidikan. Semakin rendah tingkat ekonomi sosial dan pendidikan seseorang maka semakin rendah status kesehatannya. ${ }^{6}$

Data Riset Kesehatan Dasar (Riskesdas) 2007 menunjukkan penduduk yang telah memenuhi kriteria perilaku hidup bersih dan sehat (PHBS) baik hanya sebesar 38,7\% dengan pencapaian rendah berturut-turut adalah di Papua (24,4\%), Nusa Tenggara Timur (26,8\%), Gorontalo (27,8\%) dan Sumatra Barat $(28,2 \%)^{7}$

Sementara itu, Kepala Dinas Kesehatan Jawa Barat menyatakan bahwa di Jawa Barat, masalah lingkungan berakar pada buruknya perilaku masyarakat dan rendahnya pengawasan kualitas lingkungan yang berdampak pada tingginya intensitas penyakit. Namun, dalam sisi perilaku hidup sehat dan bersih (PHBS), Jawa Barat mengalami peningkatan. Pada tahun 2012, cakupan perilaku hidup bersih dan sehat tatanan rumah tangga meningkat menjadi 56,8\%. ${ }^{8}$

Menurut hasil laporan Program perilaku hidup bersih dan sehat tatanan rumah tangga di Kota Cirebon tahun 2012 mencapai 54,4\%, sedangkan tahun 2011 pencapaian 52,3\% dari target 65\% maka hasil pada tahun 2012 meningkat $2,1 \% .^{9}$

Berdasarkan hasil laporan 10 besar penyakit di wilayah kerja Puskesmas Sunyaragi tahun 2013 terdapat beberapa penyakit terbesar yaitu ISPA $16,38 \%$, penyakit kulit $12 \%$. Kasus penyakit ini sangat dipengaruhi oleh perilaku dan sanitasi lingkungan. ${ }^{10}$

Berdasarkan data perilaku hidup bersih dan sehat tatanan rumah tangga di wilayah kerja Puskesmas Sunyaragi tahun 2013 dengan jumlah 1988 rumah tangga, status rumah tangga sehat baru mencapai 60\%, diantaranya cakupan ASI eksklusif mencapai 56\%, tidak merokok di dalam rumah mencapai 55\%. ${ }^{8}$ Padahal Rencana Strategis (Restra) Kementerian Kesehatan tahun 20102014 mencantumkan target 70\% rumah tangga sudah mempraktekkan PHBS (Perilaku Hidup Bersih dan Sehat) pada tahun 2014. ${ }^{4}$

Salah satu faktor yang mempengaruhi perilaku kesehatan seseorang adalah faktor predisposisi yaitu meliputi pengetahuan, sikap, kepercayaan, keyakinan, nilai-nilai, persepsi seseorang terhadap perilaku kesehatan. ${ }^{11}$

Penelitian yang dilakukan oleh Siti Nur Ramdaniati, 2008, menyebutkan dari hasil analisis bivariat ternyata ada hubungan antara pendidikan, pengetahuan dan sikap terhadap Perilaku Hidup Bersih dan Sehat pada tatanan rumah tangga. ${ }^{6}$

Penelitian yang dilakukan Mahfudhah, 2012 menyebutkan dari hasil analisis bivariat menunjukkan bahwa ada hubungan antara pengetahuan, sikap dan pekerjaan ibu terhadap perilaku hidup bersih dan sehat. ${ }^{12}$ Tujuan penelitian ini untuk mengetahui hubungan pengetahuan, sikap dan karakteristik ibu dengan perilaku hidup bersih dan sehat pada tatanan rumah tangga di wilayah kerja Puskesmas Sunyaragi Kota Cirebon Tahun 2014.

\section{METODE PENELITIAN}

Dalam penelitian ini penulis menggunakan metode rancangan survey analitik dengan menggunakan pendekatan Survey Analitik Cross Sectional. Variabel terikat dalam penelitian ini yaitu perilaku hidup bersih dan sehat pada ibu rumah tangga dan variabel bebasnya yaitu umur, pendidikan, status pekerjaan, pengetahuan dan sikap. ${ }^{13}$ Populasi dalam penelitian ini adalah ibu rumah tangga yang ada di wilayah kerja UPTD Puskesmas Sunyaragi periode bulan Januari Desember tahun 2013 sebanyak 2761 ibu rumah tangga. Sampel dalam penelitian ini berjumlah 97 ibu rumah tangga. Pengambilan sampel dengan cara systematic random sampling. Dalam penelitian ini menggunakan kriteria inklusi dan eksklusi. Kriteria inklusi : Memiliki anak umur $>6$ bulan -5 tahun, Sehat jasmani dan rohani, Berdomisili di Kelurahan Sunyaragi, Bersedia menjadi responden, sedangkan kriteria eksklusinya adalah ibu yang tidak memiliki anak, wanita menopause, manusia lanjut usia (manula). Analisis univariat dilakukan dengan tujuan untuk menjelaskan/mendeskripsikan karakteristik masing-masing variabel yang diteliti. Untuk analisis bivariat dilakukan uji statistik dengan chi square. 


\section{HASIL PENELITIAN}

Umur, Tingkat Pendidikan, Status Pekerjaan, Pengetahuan dan Sikap Responden

Tabel 1. Distribusi Frekuensi Menurut Umur, Tingkat Pendidikan, Status Pekerjaan, Pengetahuan dan Sikap Responden di Wilayah Kerja UPTD Puskesmas Sunyaragi Kota Cirebon Tahun 2014

\begin{tabular}{|c|c|c|}
\hline \multicolumn{3}{|c|}{ Distribusi Frekuensi Menurut Umur Responden } \\
\hline Umur & Jumlah (n) & Persentase $(\%)$ \\
\hline Dewasa akhir & 28 & 28,9 \\
\hline Dewasa awal & 69 & 71,1 \\
\hline \multicolumn{3}{|c|}{ Distribusi Frekuensi Menurut Tingkat Pendidikan } \\
\hline Tingkat Pendidikan & Jumlah (n) & Persentase (\%) \\
\hline Rendah & 39 & 40,2 \\
\hline Tinggi & 58 & 59,8 \\
\hline \multicolumn{3}{|c|}{ Distribusi Frekuensi Menurut Status Pekerjaan } \\
\hline Status Pekerjaan & Jumlah (n) & Persentase $(\%)$ \\
\hline Tidak Bekerja & 73 & 75,3 \\
\hline Bekerja & 24 & 24,7 \\
\hline \multicolumn{3}{|c|}{ Distribusi Frekuensi Menurut Pengetahuan } \\
\hline Pengetahuan & Jumlah (n) & Persentase $(\%)$ \\
\hline Kurang Baik & 44 & 45,4 \\
\hline Baik & 53 & 54,6 \\
\hline \multicolumn{3}{|c|}{ Distribusi Frekuensi Menurut Sikap } \\
\hline Sikap & Jumlah (n) & Persentase $(\%)$ \\
\hline Negatif & 41 & 42,3 \\
\hline Positif & 56 & 57,7 \\
\hline
\end{tabular}

Berdasarkan tabel 1 dapat dilihat bahwa dari 97 responden yang diteliti sebagian besar responden merupakan kelompok umur dewasa awal (26-35 tahun) yaitu sebanyak 69 responden $(71,1 \%)$, terdapat 58 responden $(59,8 \%)$ dengan tingkat pendidikan tinggi, sebanyak 73 responden $(75,3 \%)$ yang tidak bekerja, responden yang tingkat pengetahuannya baik sebanyak 53 responden $(54,6 \%)$ dan yang menunjukkan sikap positif sebanyak 56 responden $(57,7 \%)$.

\section{Perilaku Hidup Bersih dan Sehat}

Tabel 2. Distribusi Frekuensi Menurut Perilaku Hidup Bersih dan sehat Responden di Wilayah Kerja UPTD Puskesmas Sunyaragi Kota Cirebon Tahun 2014

\begin{tabular}{|c|c|c|}
\hline PHBS & $\mathrm{n}$ & $\%$ \\
\hline Tidak PHBS & 46 & 47,4 \\
\hline PHBS & 51 & 52,6 \\
\hline Total & 97 & 100,0 \\
\hline
\end{tabular}

Berdasarkan tabel 2 dapat dilihat bahwa dari 97 responden yang diteliti ternyata terdapat 46 responden $(47,4 \%)$ yang tidak berperilaku hidup bersih dan sehat dan sebanyak 51 responden $(52,6 \%)$ yang berperilaku hidup bersih dan sehat. 


\section{Hubungan antara Umur dengan Perilaku Hidup Bersih dan Sehat}

Tabel 3. Hubungan antara Umur dengan Perilaku Hidup Bersih dan sehat di Wilayah Kerja UPTD Puskesmas Sunyaragi Kota Cirebon Tahun 2014

\begin{tabular}{|c|c|c|c|c|c|c|c|}
\hline \multirow{3}{*}{ Umur } & \multicolumn{4}{|c|}{$\begin{array}{c}\text { Perilaku Hidup Bersih dan } \\
\text { Sehat }\end{array}$} & \multirow{2}{*}{\multicolumn{2}{|c|}{ Total }} & \multirow{3}{*}{$P$-Value } \\
\hline & \multicolumn{2}{|c|}{ Tidak PHBS } & \multicolumn{2}{|c|}{ PHBS } & & & \\
\hline & n & $\%$ & $\mathbf{n}$ & $\%$ & $\mathbf{n}$ & $\%$ & \\
\hline Dewasa akhir & 15 & 53,6 & 13 & 46,4 & 28 & 100,0 & 0,584 \\
\hline Dewasa awal & 31 & 44,9 & 38 & 55,1 & 69 & 100,0 & \\
\hline Total & 46 & 47,4 & 51 & 52,6 & 97 & 100,0 & \\
\hline
\end{tabular}

Berdasarkan tabel 3 menunjukkan bahwa umur responden dewasa akhir ada 28 responden yang terdiri dari 15 responden $(53,6 \%)$ tidak berperilaku hidup bersih dan sehat dan 13 responden $(46,4 \%)$ berperilaku hidup bersih dan sehat. Sedangkan umur responden dewasa awal ada 69 responden yang terdiri dari 31 responden $(44,9 \%)$ tidak berperilaku hidup bersih dan sehat dan 38 responden $(55,1 \%)$ berperilaku hidup bersih dan sehat.

Hasil uji statistik dengan Chi Square diperoleh nilai P-Value sebesar 0,584, maka Ho diterima artinya hasil uji ini tidak bermakna secara statistik, sehingga dapat disimpulkan tidak ada hubungan antara umur ibu dengan perilaku hidup bersih dan sehat pada tatanan rumah tangga di wilayah kerja UPTD Puskesmas Sunyaragi Kota Cirebon tahun 2014.

\section{Hubungan antara Tingkat Pendidikan dengan Perilaku Hidup Bersih dan Sehat}

Tabel 4. Hubungan antara Tingkat Pendidikan dengan Perilaku Hidup Bersih dan sehat di Wilayah Kerja UPTD Puskesmas Sunyaragi Kota Cirebon Tahun 2014

\begin{tabular}{|c|c|c|c|c|c|c|c|}
\hline \multirow{3}{*}{$\begin{array}{c}\text { Tingkat } \\
\text { Pendidikan }\end{array}$} & \multicolumn{4}{|c|}{ Perilaku Hidup Bersih dan Sehat } & \multirow{2}{*}{\multicolumn{2}{|c|}{ Total }} & \multirow{3}{*}{$P$ - Value } \\
\hline & \multicolumn{3}{|c|}{ Tidak PHBS } & \multirow{2}{*}{$\begin{array}{c}\text { PHBS } \\
\% \\
\end{array}$} & & & \\
\hline & $\mathbf{N}$ & $\%$ & $\mathbf{n}$ & & $\mathbf{n}$ & $\%$ & \\
\hline Rendah & 34 & 87,2 & 5 & 12,8 & 39 & 100,0 & 0,000 \\
\hline Tinggi & 12 & 20,7 & 46 & 79,3 & 58 & 100,0 & \\
\hline Total & 46 & 47,4 & 51 & 52,6 & 97 & 100,0 & \\
\hline
\end{tabular}

Berdasarkan tabel 4 menunjukkan bahwa tingkat pendidikan responden yang rendah ada 39 responden yang terdiri dari 34 responden $(87,2 \%)$ tidak berperilaku hidup bersih dan sehat dan 5 responden $(12,8 \%)$ berperilaku hidup bersih dan sehat. Sedangkan responden dengan tingkat pendidikan tinggi ada 58 responden yang terdiri dari 12 responden $(20,7 \%)$ tidak berperilaku hidup bersih dan sehat dan 46 responden $(79,3 \%)$ berperilaku hidup bersih dan sehat.

Hasil uji statistik dengan Chi Square diperoleh nilai P-Value sebesar 0,000, maka Ho ditolak artinya hasil uji ini bermakna secara statistik, sehingga dapat disimpulkan ada hubungan antara tingkat pendidikan ibu dengan perilaku hidup bersih dan sehat pada tatanan rumah tangga di wilayah kerja UPTD Puskesmas Sunyaragi Kota Cirebon tahun 2014.

\section{Hubungan antara Status Pekerjaan dengan Perilaku Hidup Bersih dan Sehat}

Tabel 5. Hubungan antara status pekerjaan dengan Perilaku Hidup Bersih dan sehat di Wilayah Kerja UPTD Puskesmas Sunyaragi Kota Cirebon Tahun 2014

\begin{tabular}{|c|c|c|c|c|c|c|c|}
\hline \multirow{3}{*}{$\begin{array}{l}\text { Status } \\
\text { Pekerjaan }\end{array}$} & \multicolumn{4}{|c|}{ Perilaku Hidup Bersih dan Sehat } & \multirow{2}{*}{\multicolumn{2}{|c|}{ Total }} & \multirow{3}{*}{$P$ Value } \\
\hline & \multicolumn{2}{|c|}{ Tidak PHBS } & \multicolumn{2}{|c|}{ PHBS } & & & \\
\hline & $\mathbf{n}$ & $\%$ & $\mathbf{n}$ & $\%$ & $\mathbf{n}$ & $\%$ & \\
\hline Tidak bekerja & 35 & 47,9 & 38 & 52,1 & 73 & 100,0 & 1,000 \\
\hline Bekerja & 11 & 45,8 & 13 & 54,2 & 24 & 100,0 & \\
\hline Total & 46 & 47,4 & 51 & 52,6 & 97 & 100,0 & \\
\hline
\end{tabular}


Berdasarkan tabel 5 menunjukkan bahwa status pekerjaan responden yang tidak bekerja ada 73 responden yang terdiri dari 35 responden $(47,9 \%)$ tidak berperilaku hidup bersih dan sehat dan 38 responden $(52,1 \%)$ berperilaku hidup bersih dan sehat. Sedangkan responden yang bekerja ada 24 responden yang terdiri dari 11 responden $(45,8 \%)$ tidak berperilaku hidup bersih dan sehat dan 13 responden $(54,2 \%)$ berperilaku hidup bersih dan sehat.

Hasil uji statistik dengan Chi Square diperoleh nilai P-Value sebesar 1,000, maka Ho diterima artinya hasil uji ini tidak bermakna secara statistik, sehingga dapat disimpulkan tidak ada hubungan antara status pekerjaan ibu dengan perilaku hidup bersih dan sehat pada tatanan rumah tangga di wilayah kerja UPTD Puskesmas Sunyaragi Kota Cirebon tahun 2014.

\section{Hubungan antara Tingkat Pengetahuan dengan Perilaku Hidup Bersih dan Sehat}

Tabel 6. Hubungan antara tingkat pengetahuan dengan Perilaku Hidup Bersih dan sehat di Wilayah Kerja UPTD Puskesmas Sunyaragi Kota Cirebon Tahun 2014

\begin{tabular}{|c|c|c|c|c|c|c|c|}
\hline \multirow{3}{*}{ Pengetahuan } & \multicolumn{4}{|c|}{ Perilaku Hidup Bersih dan Sehat } & \multirow{2}{*}{\multicolumn{2}{|c|}{ Total }} & \multirow{3}{*}{$P$ Value } \\
\hline & \multicolumn{2}{|c|}{ Tidak PHBS } & \multicolumn{2}{|c|}{ PHBS } & & & \\
\hline & $\mathbf{n}$ & $\%$ & $\mathbf{n}$ & $\%$ & $\mathbf{n}$ & $\%$ & \\
\hline Kurang & 33 & 75,0 & 11 & 25,0 & 44 & 100,0 & 0,000 \\
\hline Baik & 13 & 24,5 & 40 & 75,5 & 53 & 100,0 & \\
\hline Total & 46 & 47,4 & 51 & 52,6 & 97 & 100,0 & \\
\hline
\end{tabular}

Berdasarkan tabel 6 menunjukkan bahwa responden dengan pengetahuan kurang ada 44 responden yang terdiri dari 33 responden $(75,0 \%)$ tidak berperilaku hidup bersih dan sehat dan 11 responden $(25,0 \%)$ berperilaku hidup bersih dan sehat. Sedangkan responden dengan pengetahuan baik ada 53 responden yang terdiri dari 13 responden $(24,5 \%)$ tidak berperilaku hidup bersih dan sehat dan 40 responden $(75,5 \%)$ berperilaku hidup bersih dan sehat.

Hasil uji statistik dengan Chi Square diperoleh nilai P-Value sebesar 0,000, maka Ho ditolak artinya hasil uji ini bermakna secara statistik, sehingga dapat disimpulkan ada hubungan antara pengetahuan dengan perilaku hidup bersih dan sehat pada tatanan rumah tangga di wilayah kerja UPTD Puskesmas Sunyaragi Kota Cirebon tahun 2014.

\section{Hubungan antara Sikap dengan Perilaku Hidup Bersih dan Sehat}

Tabel 7. Hubungan antara Sikap dengan Perilaku Hidup Bersih dan sehat di Wilayah Kerja UPTD Puskesmas Sunyaragi Kota Cirebon Tahun 2014

\begin{tabular}{|c|c|c|c|c|c|c|c|}
\hline \multirow{3}{*}{ Sikap } & \multicolumn{4}{|c|}{ Perilaku Hidup Bersih dan Sehat } & \multirow{2}{*}{\multicolumn{2}{|c|}{ Total }} & \multirow{3}{*}{ P Value } \\
\hline & \multicolumn{2}{|c|}{ Tidak PHBS } & \multicolumn{2}{|c|}{ PHBS } & & & \\
\hline & $\mathbf{n}$ & $\%$ & $\mathbf{n}$ & $\%$ & $\mathbf{n}$ & $\%$ & \\
\hline Negatif & 33 & 80,5 & 8 & 19,5 & 41 & 100,0 & 0,000 \\
\hline Positif & 13 & 23,2 & 43 & 76,8 & 56 & 100,0 & \\
\hline Total & 46 & 47,4 & 51 & 52,6 & 97 & 100,0 & \\
\hline
\end{tabular}

Berdasarkan tabel 7 menunjukkan bahwa responden dengan sikap negatif ada 41 responden yang terdiri dari 33 responden $(80,5 \%)$ tidak berperilaku hidup bersih dan sehat dan 8 responden $(19,5 \%)$ berperilaku hidup bersih dan sehat. Sedangkan responden dengan sikap positif ada 56 responden yang terdiri dari 13 responden $(23,2 \%)$ tidak berperilaku hidup bersih dan sehat dan 43 responden $(76,8 \%)$ berperilaku hidup bersih dan sehat.

Hasil uji statistik dengan Chi Square diperoleh nilai P-Value sebesar 0,000, maka Ho ditolak artinya hasil uji ini bermakna secara statistik, sehingga dapat disimpulkan ada hubungan antara sikap dengan perilaku hidup bersih dan sehat pada tatanan rumah tangga di wilayah kerja UPTD Puskesmas Sunyaragi Kota Cirebon tahun 2014. 


\section{PEMBAHASAN}

\section{Hubungan antara Umur dengan Perilaku Hidup Bersih dan Sehat}

Umur adalah umur yang terhitung saat dilahirkan sampai saat akan berulang tahun. Semakin cukup umur, tingkat kematangan dan kekuatan seseorang akan lebih matang dalam berfikir dan bekerja. ${ }^{11}$ Dari hasil penelitian yang telah penulis lakukan dengan menggunakan uji statistik $C h i$ Square diperoleh nilai $P$-Value sebesar 0,584 , maka Ho diterima artinya hasil uji ini tidak bermakna secara statistik, sehingga dapat disimpulkan tidak ada hubungan antara umur ibu dengan perilaku hidup bersih dan sehat pada tatanan rumah tangga di wilayah kerja UPTD Puskesmas Sunyaragi Kota Cirebon tahun 2014.

Hal ini tidak sesuai dengan penelitian yang dilakukan oleh Herman Setyono,P, 1997 dalam penelitiannya tentang gambaran Pengetahuan, sikap dan karakteristik sosio demografi ibu dalam pemanfaatan pertolongan persalinan di Kabupaten Sumedang Jawa Barat, menyatakan bahwa semakin tinggi umur ibu maka akan semakin memilih bidan untuk menolong persalinannya. ${ }^{14}$

Perilaku merupakan respon dari stimulus atau rangsangan dari luar organisme, dalam hal ini manusia. Namun dalam memberikan respon setiap orang berbeda-beda karena dipengaruhi faktorfaktor internal dan eksternal dari orang itu sendiri. Salah satu faktor internal yang mempengaruhi orang tersebut untuk mengambil keputusan berperilaku tertentu yaitu umur. Semakin tinggi umur seseorang maka akan semakin matang daya berfikirnya dan banyak pengalaman untuk berperilaku tertentu, termasuk perilaku hidup bersih dan sehat.

Dalam penelitian hubungan pengetahuan, sikap dan karakteristik ibu dengan perilaku hidup bersih dan sehat pada tatanan rumah tangga di wilayah kerja UPTD Puskesmas Sunyaragi Kota Cirebon tahun 2014 didapatkan hasil bahwa tidak ada hubungan yang bermakna antara umur ibu rumah tangga dengan perilaku hidup bersih dan sehat. Hal ini dapat disebabkan oleh variabel lain, salah satunya yaitu kurang maksimalnya kegiatan penyuluhan tentang perilaku hidup bersih dan sehat. Hal ini sesuai dengan penelitian Rio, 2005 yang menjelaskan bahwa ada hubungan antara tingkat keterpaparan penyuluhan tentang perilaku hidup bersih dan sehat dengan perilaku hidup bersih dan sehat pada ibu rumah tangga di Kelurahan Sawangan Depok.

\section{Hubungan antara Tingkat Pendidikan dengan Perilaku Hidup Bersih dan Sehat}

Pendidikan berarti bimbingan yang diberikan oleh seseorang terhadap perkembangan orang lain menuju ke arah suatu cita-cita tertentu. Makin tinggi tingkat pendidikan seseorang, maka makin mudah dalam memperoleh dan menerima informasi. Sehingga kemampuan ibu lebih berfikir secara rasional. ${ }^{15}$ Dari hasil penelitian yang telah penulis lakukan dengan menggunakan uji statistik dengan Chi Square diperoleh nilai $P$-Value sebesar 0,000, maka Ho ditolak artinya hasil uji ini bermakna secara statistik, sehingga dapat disimpulkan ada hubungan antara tingkat pendidikan ibu dengan perilaku hidup bersih dan sehat pada tatanan rumah tangga di wilayah kerja UPTD Puskesmas Sunyaragi Kota Cirebon tahun 2014.

Hasil penelitian yang sama yang dilakukan oleh Eka Afrianti Putri di wilayah kerja Puskesmas Lubuk Alung tahun 2009, menunjukkan ada hubungan antara tingkat pendidikan dengan perilaku hidup bersih dan sehat. ${ }^{10}$ Hasil penelitian lain yang dilkukan oleh Amalia, 2009, menemukan adanya hubungan antara tingkat pendidikan masyarakat dengan perilaku hidup bersih dan sehat di Pasar Kliwon dan Jebres Kota Surakarta. ${ }^{10}$

Salah satu faktor yang mempengaruhi perilaku kesehatan seseorang yaitu faktor predisposisi yang meliputi pengetahuan, kepercayaan, keyakinan, nilai-nilai dan persepsi seseorang terhadap perilaku kesehatan. Pendidikan merupakan faktor yang berpengaruh dalam membentuk pengetahuan, sikap, persepsi, kepercayaan dan penilaian seseorang terhadap kesehatan. ${ }^{9}$ Sehingga dapat disimpulkan bahwa semakin tinggi tingkat pendidikan seseorang maka akan semakin sadar dan peduli terhadap kebersihan diri dan lingkungannya.

\section{Hubungan antara Status Pekerjaan dengan Perilaku Hidup Bersih dan Sehat}

Pekerjaan adalah simbol status seseorang dimasyarakat. Pekerjaan adalah jembatan untuk memperoleh uang (ekonomi) dalam rangka memenuhi kebutuhan hidup dan untuk mendapatkan 
tempat kesehatan yang diinginkan. ${ }^{15}$ Dari hasil penelitian yang telah penulis lakukan dengan menggunakan uji statistik dengan Chi Square diperoleh nilai P-Value sebesar 1,000, maka Ho diterima artinya hasil uji ini tidak bermakna secara statistik, sehingga dapat disimpulkan tidak ada hubungan antara status pekerjaan ibu dengan perilaku hidup bersih dan sehat pada tatanan rumah tangga di wilayah kerja UPTD Puskesmas Sunyaragi Kota Cirebon tahun 2014.

Penelitian tentang gambaran pengetahuan, sikap dan karakteristik sosio demografi ibu dalam pemanfaatan pertolongan persalinan di Kabupaten Sumedang Jawa Barat, dalam penelitian yang serupa menyatakan bahwa semakin tinggi tingkat pendapatan ibu yang bekerja akan meningkatkan pencarian persalinan oleh tenaga kesehatan. Hal ini menunjukkan bahwa ada hubungan antara ibu yang bekerja dengan pemilihan pertolongan persalinan oleh tenaga kesehatan yang merupakan salah satu indikator PHBS (perilaku hidup bersih dan sehat). ${ }^{14}$

Ibu rumah tangga yang bekerja akan menambah penghasilan keluarga untuk memenuhi kebutuhan sehari-hari. Dengan demikian alokasi pendapatan untuk kebutuhan kesehatan bertambah besar. Namun hasil penelitian pada ibu rumah tangga di wilayah kerja UPTD Puskesmas Sunyaragi Kota Cirebon menunjukkan bahwa tidak ada hubungan yang bermakna antara status pekerjaan dengan perilaku hidup bersih dan sehat. Peneliti berasumsi hal ini dapat dikarenakan penghasilan yang diperoleh ibu rumah tangga tersebut tidak dalam jumlah yang besar sehingga pendapatan mereka tidak besar dan hanya cukup untuk menambah biaya untuk kebutuhan sehari-hari. Selain itu juga dapat disebabkan oleh kesibukan ibu yang bekerja sehingga hanya memiliki sedikit waktu untuk mengatur menu keluarga dan menjaga kebersihan diri dan lingkungannya.

\section{Hubungan antara Pengetahuan dengan Perilaku Hidup Bersih dan Sehat}

Pengetahuan adalah hasil dari tahu dan terjadi setelah orang melakukan pengindraan terhadap suatu objek tertentu. Pengindraan terjadi melalui panca indra penglihatan, pendengaran, penciuman, rasa dan raba. Sebagian besar pengetahuan manusia diperoleh melalui mata dan telinga. ${ }^{11}$

Berdasarkan hasil uji statistik dengan Chi Square diperoleh nilai $P$-Value sebesar 0,000, maka Ho ditolak artinya hasil uji ini bermakna secara statistik, sehingga dapat disimpulkan ada hubungan antara pengetahuan dengan perilaku hidup bersih dan sehat pada tatanan rumah tangga di wilayah kerja UPTD Puskesmas Sunyaragi Kota Cirebon tahun 2014.

Berdasarkan penelitian tentang hubungan pengetahuan dan sikap ibu rumah tangga terhadap perilaku hidup bersih dan sehat, menyatakan bahwa ibu yang memiliki pengetahuan tinggi tentang perilaku hidup bersih dan sehat berperan bagi keluarganya untuk berperilaku hidup bersih dan sehat dibandingkan dengan ibu yang memiliki pengetahuan yang rendah tentang perilaku hidup bersih dan sehat. ${ }^{16}$ Pengetahuan merupakan faktor yang sangat penting dalam membentuk perilaku seseorang. Dari pengalaman dan penelitian sebelumnya terbukti bahwa perilaku didasari oleh pengetahuan akan bertahan lebih lama daripada perilaku yang tidak didasari oleh pengetahuan.

\section{Hubungan antara Sikap dengan Perilaku Hidup Bersih dan Sehat}

Sikap merupakan reaksi atau respon yang masih tertutup dari seseorang terhadap suatu stimulus atau objek. Sikap merupakan kesiapan untuk bereaksi terhadap objek di lingkungan tertentu sebagai suatu penghayatan terhadap objek. ${ }^{3}$ Dari hasil penelitian yang telah penulis lakukan dengan menggunakan uji statistik dengan Chi Square diperoleh nilai P-Value sebesar 0,000, maka Ho ditolak artinya hasil uji ini bermakna secara statistik, sehingga dapat disimpulkan ada hubungan antara sikap dengan perilaku hidup bersih dan sehat pada tatanan rumah tangga di wilayah kerja UPTD Puskesmas Sunyaragi Kota Cirebon tahun 2014.

Hal ini sesuai dengan penelitian hutagalung tentang Faktor-faktor yang mempengaruhi perilaku ibu dalam menimbangkan anaknya di Posyandu Kotif, Palu, dinyatakan bahwa semakin positif sikap ibu terhadap posyandu semakin besar proporsi ibu-ibu yang menimbangkan anaknya. Dimana menimbang bayi di posyandu merupakan salah satu indikator perilku hidup bersih dan sehat. ${ }^{14}$ Sikap secara nyata menunjukkan adanya kesesuaian reaksi terhadap stimulus tertentu yang dalam kehidupan sehari-hari merupakan reaksi yang emosional terhadap stimulus sosial. ${ }^{17}$ 
Penentuan sikap yang utuh diperlukan komponen kepercayaan, emosional dan kecenderungan. Perilaku yang didasari oleh sikap yang positif akan bersifat long lasting (bertahan lama) dibandingkan dengan perilaku yang tidak didasari oleh sikap positif.

\section{SIMPULAN}

1. Tidak ada hubungan antara umur ibu dengan perilaku hidup bersih dan sehat pada tatanan rumah tangga di wilayah kerja UPTD Puskesmas Sunyaragi Kota Cirebon tahun 2014.

2. Ada hubungan antara tingkat pendidikan ibu dengan perilaku hidup bersih dan sehat pada tatanan rumah tangga di wilayah kerja UPTD Puskesmas Sunyaragi Kota Cirebon tahun 2014.

3. Tidak ada hubungan antara status pekerjaan ibu dengan perilaku hidup bersih dan sehat pada tatanan rumah tangga di wilayah kerja UPTD Puskesmas Sunyaragi Kota Cirebon tahun 2014.

4. Ada hubungan antara pengetahuan dengan perilaku hidup bersih dan sehat pada tatanan rumah tangga di wilayah kerja UPTD Puskesmas Sunyaragi Kota Cirebon tahun 2014.

5. Ada hubungan antara sikap dengan perilaku hidup bersih dan sehat pada tatanan rumah tangga di wilayah kerja UPTD Puskesmas Sunyaragi Kota Cirebon tahun 2014.

\section{SARAN}

1. Bagi Dinas Kesehatan Kota Cirebon

1) Bagi Dinas Kesehatan Kota Cirebon disarankan dapat terus berupaya meningkatkan program kesehatan masyarakat yang berhubungan dengan perilaku hidup bersih dan sehat.

2) Memberikan intervensi yang tepat sesuai sasaran. Merencanakan dan menganggarkan dana untuk membuat program khusus terkait PHBS yang bersifat promotif seperti penyuluhan secara langsung maupun tidak langsung melalui media spanduk, poster, media elektronik dan lain-lain.

2. Bagi UPTD Puskesmas Sunyaragi

1) Bagi puskesmas setempat hasil penelitian ini dapat digunakan sebagai bahan pertimbangan untuk terus mengembangkan dan menjalankan program PHBS agar lebih ditingkatkan lagi, selain didata sebaiknya hasil pendataan tersebut digunakan sebagai dasar untuk perbaikan sehingga tiap pendataan ada perubahan ke arah yang lebih baik lagi.

2) Diharapkan agar petugas puskesmas lebih meningkatkan pemberian penyuluhan kepada masyarakat agar pengetahuan dan pemahaman masyarakat terhadap perilaku hidup bersih dan sehat, dan masyarakat lebih bisa menjaga kesehatan keluarganya dan menerapkan perilaku hidup bersih dan sehat dilingkungan keluarga setiap hari.

3) Diharapkan ada peningkatan tenaga promosi kesehatan di puskesmas dari segi kualitas dan kuantitasnya serta puskesmas menggandakan buku pedoman dan kartu PHBS agar petugas yang melaksanakan tugas mempunyai sarana dan mampu meningkatkan kualitas pemahaman petugas.

4) Diharapkan ada peningkatan peran serta masyarakat dalam mengenal PHBS dengan mengikuti penyuluhan yang dilaksanakan oleh pihak Puskesmas.

3. Bagi Ibu Rumah Tangga

Penelitian ini diharapkan agar ibu-ibu lebih termotivasi untuk meningkatkan pengetahuan, sikap, dan perilaku hidup bersih dan sehat agar menjadi lebih baik lagi. Pengetahuan tersebut bisa didapat dari buku, majalah, televisi, radio ataupun berdasarkan dari pengalaman

\section{DAFTAR PUSTAKA}

1. Bappenas. Undang-Undang Republik Indonesia No. 17 Tahun 2007 Tentang Rencana Pembangunan Jangka Panjang Nasional Tahun 2005-2025. Diakses tanggal 19 September 2013, diunduh dari: http:www.bappenas.go.id/need/

2. Departemen kesehatan RI. Keluarga sehat investasi bangsa.[online]. November 2010. Diakses tanggal 2 Desember 2013, diunduh dari http://www.Depkes.go.id/index.php/berita/pressrelease/1309-keluarga-sehat-investasi-bangsa.html

3. Soekidjo Notoatmodjo. Pendidikan dan perilaku kesehatan. Jakarta : Rineka Cipta ; 2003 
4. Depkes RI. Pengkajian Kuantitatif Rumah Tangga Sehat dengan Metode Survey Cepat, seri 1. Jakarta : Depkes RI; 2004

5. Lukas JV. Gambaran Pengetahuan Masyarakat Terhadap Perilaku Hidup Bersih dan Sehat di Desa Kaweng Kecamatan Kakas tahun 2011. Skripsi. Universitas Sam Ratulangi Manado ; 2011

6. Siti Nur Ramdaniati. Pengetahuan dan Sikap terhadap Perilaku Hidup Bersih dan Sehat pada Ibu Rumah Tangga RW 04 Kelurahan Manggarai Jakarta tahun 2008. Jakarta : Skripsi FKM UI ; 2008

7. Hilya Haniek. Hubungan antara Pengetahuan dan Sikap dengan Perilaku Hidup Bersih dan Sehat pada Ibu Rumah Tangga di Kecamatan Lubuk Sikaping tahun 2011. Jakarta : Skripsi PSPD FKIK UIN Syarif hidayatullah ; 2011

8. Pagelaran wayang golek. Diakses tanggal 4 Februari 2014, diunduh dari http://stbmindonesia.org/dkconten.php?id=6592\&r=301

9. Dinas Kesehatan Kota Cirebon Provinsi Jawa Barat. Profil Kesehatan Provinsi Jawa Barat Tahun 2010. Jawa Barat : Dinas Kesehatan Provinsi Jawa Barat Tahun 2011

10. Amalia I. Hubungan antara Pendidikan, Pendapatan dan Perilaku Hidup Bersih dan Sehat (PHBS) pada Pedagang Hidangan Istimewa Kampung (HIK) di Pasar Kliwon dan Jebres Kota Surakarta tahun 2009. Laporan Penelitian. UMS. Surakarta. Diakses tanggal 2 Desember 2013, diunduh dari: http://etd.eprints.ums.ac.id.

11. Soekidjo Notoatmodjo. Promosi kesehatan dan ilmu kesehatan Perilaku. Jakarta : PT. Rineka Cipta ; 2007

12. Desi Mahfudhah. Hubungan Pengetahuan, Sikap dan Pekerjaan Ibu terhadap Perilaku Hidup Bersih dan Sehat pada Tatanan Rumah Tangga di Desa Reukih Dayah Kecamatan Indrapuri Kabupaten Aceh Besar tahun 2012. Banda aceh : Skripsi Stikes U'Budiyah Banda Aceh ; 2012

13. Soekidjo Notoatmodjo. Metodologi Penelitian Kesehatan. Edisi revisi. Jakarta : Rineka Cipta ; 2002.

14. Potter AP. Perry AG. Alih bahasa. Yasmin et.al. Buku Ajar Fundamental Keperawatan, Konsep Proses dan Praktik. Edisi 4. Jakarta : EGC ; 2005

15. Suparyanto. Konsep Paritas Partus. Diakses tanggal 8 Desember 2013, diunduh dari http://dr.suparyanto.blogspot.com

16. Lili Suryani. Hubungan Pengetahuan dan Sikap Ibu Rumah Tangga terhadap PHBS di Kelurahan Payo Selincah tahun 2013. Jambi : Skripsi FKIK Universitas Jambi ; 2013 